\title{
DEVELOPING VIDEO BLOG AS TEACHING MEDIA IN SPEAKING OF REPORT TEXT FOR GRADE XI VOCATIONAL HIGH SCHOOL
}

\begin{abstract}
AN ARTICLE
Submitted in Partial Fulfillment of the Requirements for the Degree of Sarjana Pendidikan
\end{abstract}

\section{By}

TRIWANDANA

Registration Number: 2133121065

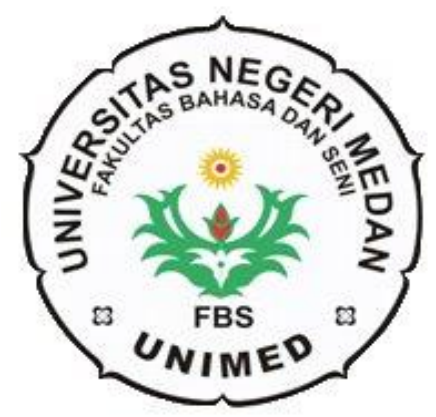

ENGLISH AND LITERATURE DEPARTMENT

FACULTY OF LANGUAGES AND ARTS STATES UNIVERSITY OF MEDAN 2018 


\title{
ARTIKEL \\ DEVELOPING VIDEO BLOG AS TEACHING MEDIA IN SPEAKING OF REPORT TEXT FOR GRADE XI VOCATIONAL HIGH SCHOOL
}

\author{
Disusun dan Diajukan oleh: \\ Triwandana \\ Registration Number: 2133121065
Telah diverifikasi dan dinyatakan memenuhi syarat untuk diunggah pada jurnal online
Medan, Maret 2018
Menyetujui

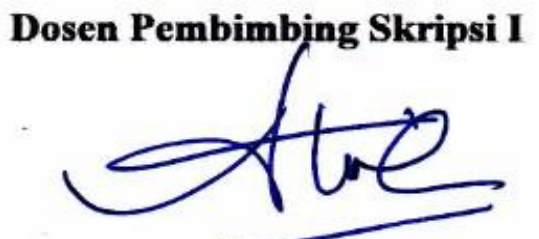

Prof. Dr. H. Sumarsih, M.Pd. NIP. 195810211983032002
Dosen Pembimbing Skripsi II

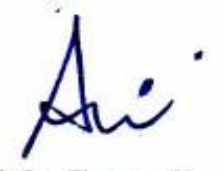

Anggraini Thesisia Saragih, S.Pd., M.Hum. NIP. 198011112008122003

Ka. Program Studi

Pendidikan Bahasa I fygris

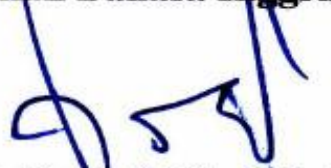

Nora Ronita Dend, S.Pd., S.S., M.Hum.

NIP. 198005222008122003 


\title{
DEVELOPING VIDEO BLOG AS TEACHING MEDIA IN SPEAKING OF REPORT TEXT FOR GRADE XI VOCATIONAL HIGH SCHOOL
}

\author{
* Triwandana \\ ** Sumarsih \\ ** Anggraini Thesisia Saragih
}

\begin{abstract}
Triwandana. Registration Number: 2133121065. Developing Video Blog As Teaching Media In Speaking Of Report Text For Grade XI Vocational High School. A Thesis. English Educational Program, State University of Medan, 2018.

This study aimed to develop Video Blog as Teaching Media for Students of Multimedia Programme. This study was conducted by using Research and Development (R \& D).

Instruments for collecting data were syllabus, questionnaire and interview. The data was gathered by administering interview to the teacher and distributing questionnaires to the students. The result of this study was developed Video Blog which contained explanation, students' activities and the example of report text in spoken. The average scores of media's assesment were 4.04 from English teacher and 4.56 from English lecturer. It means the developed Video Blog as Teaching Media were categorized as very good or very appropriate for students of Multimedia Programme.
\end{abstract}

Key words: Report text, Research and Development $(R \& D)$, Report Text

*Graduate

** Lecturer 


\section{INTRODUCTION}

\section{Background of the study}

In this modern era English has become important thing to be mastered, because English as International language is used in many countries as tool to communicate globally. English is not only used in education environment, but also in many fields such as technology and business. In this competitive era, job application also look for people who skilled in English. This is why English should be learnt. In learning English, there are four skills must be learnt, they are reading, listening, writing and speaking. Speaking is one of important skills in learning English, but many students did not want to learn it because they thought speaking English is difficult, uninteresting and unnecessary. Many students in senior high school or vocational high school show unsatisfy result in speaking competence. They were not confident and fluent when speaking in front of the class, they also miss promounce and difficult to express their idea when speaking.

The problem may be affected by many factors, such as the teaching method and technique applied by teachers, media used in learning process, students' enthusiasm and motivation. In fact, based on the writer's observation in SMK MULTIKARYA, the teacher were not appropriately teaching speaking skill. The teachers did not use any teaching media and tend to use only textbook in teaching and learning process. The students also rarely given appropriate model in practicing 
speaking skill. Teachers is the only model in practicing pronunciation, fluency and accuracy.

Usually picture is the common teaching media used in teaching speaking. Unfortunately, using picture as teaching media in speaking did not give satisfy result. It may cause due to the fact that picture seem uninteresting if the picture is not unique. Other disadvantages of picture are picture is depicting specific purpose that may be difficult to locate and picture doesn't give real situation and motion to the topic being taught like video does.

In this case, the teacher should provide learning media, such as video to atrract student in learning English especially in speaking. Gilakjani (2012) states that multimedia has been successfully applied to many courses in order to provide a wide variety of learning styles or modalities. It means that multimedia is appropriate for any other material in teaching and learning process. Moreover, the use of technologies, Internet, computers, and others interesting media, in teaching and learning process can be very helpful. Considering those technologies can provide the opportunity to enhance both teachers and students' knowledge and skill. Technology has the power to utterly transform learning, there are occasions where it can actually serve to reinforce linguistic, social and cultural hegemonies, rather than challenging them (Rasool, 2000 cited in Motteram, 2013).

Thus, this study will be focus on developing video blog (Vlog) as teaching media to teach speaking. Basically, Vlog is Blog or Web-log that usually contain only 
text or picture but rather than in text form, Vlog transform all those things into video form. Moreover, Vlog is recorded of thoughts, opinions or experiences that filming and publishing on the internet.

Using Vlog as teaching media to teach speaking skill is good because students can practice speak English more than did not use it. It is suported by Stempleski cited in Richard \& Renandya (2002) stating with careful and systematic Technologies in the Classroom planning, video-based lessons can be highly stimulating, and provide a rich resource for language learning. Vlog provide opportunity to share thoughts, opinions and experiences in group or individually.

Vlog gives positive impact to students' ability in speaking. Using Vlog as teaching media not only improve sepaking ability but also hopefully affect students' enthusiasm in learning English generally and speaking English particularly. Thus, this research is formulated as "Developing Video Blog as Teaching Media of Speaking in Report Text"

\section{REVIEW OF LITERATURE}

Educational media refer to media developed specifically for the purposes of educating. The most common example would be textbooks. All educational media are characterized by a selection of content which is then logically ordered so as to develop learning (Bertram et al, 2002). Based on the definitions above media has an important role in teaching and learning process in facilitating teaching-learning and atrracting students' enthusiasm. 
Speaking is important in human life. People use speaking to communicate orally with others. Unlike writing, speaking happens in realtime and it can not be revised what we want to say. In education, speaking is a crucial part of English as foreign language learning and teaching. According to Bashir et al (2011) speaking is productive skill in the oral mode. It is like the other skills, is more complicated than it seems at first and involves more than just pronouncing words.

\section{RESEARCH METHODOLOGY}

\section{Research Design}

This research was conducted based on educational research and development (R\&D). Educational research and development is a process used to develop validates educational products e.g. textbook, instructional films, method of teaching or method for organizing instruction (Borg \& Gall, 2003.) In this research, the ten stages of R\&D were simplified into six stages because it depend on the research needed, those are : 1) Evaluating the existing materials, 2) conducting need analysis, 3) writing the syllabus, 4) Developing teaching materials, 5) Evaluating and revising the materials, 6) Writing the final product.

\section{The Instrument of Data Collection}

The data in this research were collected by using interview and questionnaire. Questionnaire was given to students to acquire data about students' need, problem and their interesting in teaching and learning English process, particularly in speaking. Interview was given to English teachers to find detail information about 
students' need, difficulty to achieve objectives of teaching and learning speaking and appropriateness of teaching media given to students.

\section{Technique of Data Analysis}

The questionnaires from students and interview from teacher were analyzed to answer students' problem and find appropriate teaching media based on students' need. Then these data are used to develop new teaching media.

\section{FINDING}

1. Gathering information and data: There were some information gathered, such as teachers' interview and students' questionnaires. The interview session was administrated to English teacher. The questionnaires were distributed to 26 students of grade XI Multimedia programme in SMK Multi Karya

2. Need Analysis: Need analysis was required before developing the media. The researcher determined the students' need by arranging them according to the priorities with reference to the data from questionnaire and interview. The result of need analysis were (1) the students needed speaking to support their future career (2) the media wanted by the students was video (3) the media should be interesting, creative and innovative.

3. Developing media: The media developed was video blog. The content of the video blog was taken from pardiyono and Wikipedia. The video blog was edited by using Adobe Premiere Pro CC 2017 then the video blog was burned into CD or DVD.. 
4. Validating media by Experts: After developing the media, then the media was validated or evaluated by two experts. There were 23 questions distributed to the expert that covered four dimension which were included dimension of linguistic, process, content and layout. The average score from the teacher was 4.04 or percentage $80 \%$, the average score from the lecturer was 4.56 or percentage $91.3 \%$ and average of total score from those two experts was 4.25. Based on the interval score (Rudianto cited from Yulihar, 2016) the developed teaching media was considered as very appropriate.

5. Revising media by Experts' Suggestions: The developed teaching media had been evaluated by the experts. There were some revisions as suggested by the experts. The first expert suggested to improve the audio quality and synchronize the audio with video. The second expert suddested to add the information about minimum requirements specification of computer to play the video and give some activities for students in the middle of video

6. Final Product: After revising the product based on experts' suggestion, the final product consisted of two videos blog. The first video contains the explanation about definition of report text, social function, generic structure and language features and some exercises such as analyse the generic structure and language features, rearrange jumble paragraph and ask the students to answer orally. The second video contains the example of report text in spoken and task for the students to create their own report text in spoken. 


\section{CONCLUSION AND SUGGESTIONS}

\section{Conclusion}

1. The researcher concluded that the relevant teaching media in speaking report text for student of multimedia programme was two videos blog: (1) video contains explanation and exercises (2) video contains example and task.

2. The videos blog as teaching media of speaking in report text was designed based on need analysis. In addition, video blog as teaching media was designed by using several steps, they are: (1) Gathering data and information, (2) Need analysis, (3) Media design, (4) Validating to experts, (5) Revising, (6) Final product. Furthermore, The average scores of media assessment were 4.04 from English teacher and 4.56 from English lecturer, which is it means that developed videos blog were categorized as very appropriate for students of multimedia programme.

\section{Suggestion}

Based on the conclusions above, some suggestions are given as follows:

1. The students should learn independently and take more practice in speaking by using video blog, because video blog can provide interesting material and comunnicative tasks, so the student accustomed in speaking English.

2. The teachers should use the video blog to attract students' enthusiasm and provide the opportunity to practice speaking English in teaching report text, because video blog contains interesting exercise. 
3. School should fasilitate the teachers and other researchers in developing video blog, because the video blog can be used by the students to study and practice speaking independently.

4. And other researchers should conduct further studies on developing video blog for another lesson which is relevant to students' need in order to increase students' comprehension and enthusiasm. 


\section{REFERENCES}

Bashir, M. Azeem, M \& Dogar, A.H. 2011. Factor Effecting Students' English Speaking Skills. British Journal of Arts and Social Sciences, Vol. 2, No. 1.

Bertram, C. Ranby, P. Adendorff, M. Reed, Y. \& Roberts, N. 2002. Using Media in Teaching. Oxford: Saide.

Borg. W.R. and Gall, M.D. 2003. Educational Research: An Introduction. New York: Longman.

Gilakjani, Abbas Pouhosein, November 2012. Research and Language Teaching Journal. A Study on the Impact of Using Multimedia to Improve the Quality of English Language Teaching. 3 (6).

Motteram, G. (Ed). 2013. Innovations in learning technologies for English language teaching.London: British Counsil.

Richard, J.C. Renandya, W.A. 2002. Methodology in Language Teaching. New York: Cambridge University Press. 